\title{
STRATEGI PENGELOLAAN SANGGAR SENI ANACARAKA DALAM MEWADAHI BAKAT ANAK-ANAK DI PEGUNUNGAN KINTAMANI BALI
}

\author{
I Putu Ardiyasa \\ tuardiyasa@gmail.com
}

\begin{abstract}
Abstrak
Penelitian ini mengkaji tentang pengelolaan Sanggar Seni Anacaraka dalam upaya mewadahi bakat anak-anak di Kintamani, Bali. Tujuan penelitian ini adalah untuk menjawab dua permasalahan yang diajukan : pertama strategi apa yang semestinya diterapkan oleh pengelola dalam rangka menjaga eksistensi di tengah persaingan global; kedua bagaimana rancangan penerapan strategi pada Sanggar Seni Anacaraka. Untuk membedah permasalahan tersebut, digunakan pendekatan kualitatif, dengan menggunakan alat pengumpulan data berupa observasi, wawancara, dan studi kepustakaan. Analisis data dilakukan dengan metode SWOT untuk mengkaji permasalahan baik dalam lingkup internal dan eksternal. Sumber data diperoleh di lokasi penelitian dengan menentukan key person yang berkompeten dan sumber data tertulis yang mendukung dan relevan. Hasil dari penelitian ini menunjukkan bahwa Sanggar Seni Anacaraka perlu melakukan pemilihan strategi berupa penggunaan setiap kekuatan (strenght) untuk menghadapi segala ancaman (treath) dengan melakukan penetrasi pasar, pengembangan pasar, pengembangan produk dan diversifikasi terkait. Selain itu, pengelolaan Sanggar Seni Anacaraka menggunakan strategi tumbuh dan membangun karena posisi sanggar yang baru berdiri dan belum memiliki kekuatan yang bisa mendukung pembangunan sanggar. Bentuk edukasi seperti ini akan terus berkembang dengan keterlibatan masyarakat dan pemerintah bersama pihak pengelola, sehingga ke depan mampu mengedukasi anak-anak secara berkelanjutan dalam rangka menjaga keberlangsungan hidup seni.
\end{abstract}

Kata kunci : sanggar seni anacaraka, edukasi, strategi pengelolaan

\section{Pendahuluan}

Sebuah organisasi untuk menghadirkan seni yang terbaik, maka harus ada perencanaan yang matang yang berbasis pada publik (audiens), dan nilai. Artinya, seni yang dihadirkan menarik dan relevan dengan situasi pentas. Ketersediaan Sumber Daya Manusia (SDM) sebagai salah satu aset organisasi diberdayakan dengan merancang strategi yang sesuai dengan misi ke depan. Setiap peralihan pasti memunculkan keinginan yang berbeda dari publik (audiens), oleh sebab itu strategi yang dihadirkan juga memikirkan perbedaan-perbedaan pada setiap perencanaan kegiatan (Kaiser, 2011: 5).

Selain itu perencanaan strategis organisasi tersebut juga diimplementasikan berdasarkan audit internal (kekuatan, kelemahan) dan eksternal (peluang dan ancaman) yang bertujuan 
untuk mengembangkan daftar terbatas dari peluang dan kekuatan yang dapat menguntungkan dan kelemahan dan ancaman harus dihindari (David, 2010: 120).

Hal-hal strategis ini yang sering luput dari perhatian pengelola dalam mendirikan organisasi, komunitas, yayasan, padepokan, atau sanggar seni.

Organisasi seni yang ada memiliki peran penting dalam menjaga keberlangsungan hidup seni baik dalam menghadirkan kesenian dan meregenerasi calon seniman. Pada persaingan global ini, wadah seni menjadi penting, bukan hanya sebagai tempat seni, tapi juga sebagai ruang edukasi serta tempat berkumpulnya sekelompok orang atau masyarakat (Jeannie Park, 2015: 6).

Jika pengelola tidak mampu menjaga keberlangsungan organisasinya maka ruang-ruang seni tersebut akan semakin berkurang. Salah satu penyebabnya adalah, kurangnya perhatian dalam memanfaatkan kekuatan, menghindari kelemahan, mencari peluang serta peka terhadap ancaman yang ada.

Tema ini penting bagi peneliti untuk dibahas, mengingat kondisi saat ini banyak organisasi seni yang tidak mampu bertahan dalam jangka waktu yang panjang di tengah persaingan global. Kondisi internal organisasi yang masih lemah, mengakibatkan komunikasi tidak efektif, sehingga visi-misi organisasi tidak mampu diimplementasikan dengan baik. Pengelola juga kesulitan menemukan referensi relevan yang dapat mendukung pengelola membangun ruang seni. Adanya penelitian ini, diharapkan bisa menjadi referensi yang dimanfaatkan oleh pengelola organisasi seni baik yang sudah dan belum berbadan hukum. Dengan demikian, penting adanya audit eksternal dan internal dalam rangka menerapkan strategi pengembangan usaha.

Berdasarkan hal tersebut, peneliti mencoba mengangkat Sanggar Seni Anacaraka di Kintamani, Bali, sebagai objek penelitian. Sanggar Seni Anacaraka adalah salah satu organisasi seni yang bernafaskan tradisi yang berada di Kintamani, sebuah daerah dataran tertinggi di Bali. Organisasi ini, secara umum dapat dikatakan masih muda, karena baru berdiri sejak tahun 2011. Sanggar Seni Anacaraka didirikan oleh Putu Ardi seorang seniman muda lulusan Insitut Seni Indonesia Denpasar dengan tujuan untuk mewadahi minat dan bakat seni anak-anak pegunungan, serta dapat dijadikan sebagai ruang untuk bermain dan melakukan hal-hal yang bermanfaat bagi anak-anak yang hidupnya jauh dari hiruk-pikuk perkotaan.

Dengan dukungan orang tua, dan semangat pengabdian besar, walaupun hanya memanfaatkan modal kecil, Putu bisa terus konsisten mewadahi minat anak-anak tanpa meminta imbalan sepeserpun. Dalam proses kegiatannya, Sanggar Seni Anacaraka menggunakan konsep ngayah, dimana mereka (seniman) mengorbankan tenaga dan pikirannya untuk generasi muda dan kelangsungan hidup seni. Tujuannya untuk menciptakan generasi muda berkarakter yang mencintai seni dan budaya serta terlibat dalam menjaga kelangsungan hidup seni dan budaya. Tapi sayangnya, pihak pengelola belum memiliki struktur oganisasi yang jelas, kurangnya SDM dan belum adanya rencana strategis untuk pengembangan usaha ke depannya.

Persoalan ini membuat Sanggar Seni Anacaraka menjadi objek yang menarik bagi peneliti untuk dikaji, karena dengan pengelolaan yang serba kekurangan, sanggar ini masih konsisten selama 5 tahun mengedukasi anak-anak. Dalam hal ini mungkin pengelola sanggar sudah menemukan kepentingan dan pentingnya seni tersebut untuk dikelola. Dengan demikian, peneliti merumuskan permasalahan penelitian menjadi dua, yaitu: pertama strategi apa yang 
semestinya diterapkan oleh Sanggar Seni Anacaraka dalam rangka menjaga eksistensi di tengah persaingan global; kedua bagaimana rancangan penerapan strategi pada sanggar Anacaraka?

\section{Metode Penelitian}

\section{Observasi}

Observasi dilakukan pada bulan Juli 2016 dengan melakukan pengamatan, yang meliputi kegiatan pemantauan perhatian terhadap sesuatu objek dengan menggunakan alat seadanya, berupa catatan lapangan dan ingatan peneliti. Kegiatan ini dilakukan di lokasi Sanggar Seni Anacaraka di Banjar Sabang, desa Selulung, Kintamani, Bali. Adapun yang pewawancara lakukan saat observasi, adalah (1) melihat kegiatan Sanggar Seni Anacaraka; (2) memperhatikan aktivitas pengelola; dan (3) mengamati proses latihan dan pementasan.

\section{Wawancara}

Terdapat beberapa tahapan mempersiapkan wawancara yang diterapkan dalam penelitian ini, mengacu dari pandangan Creswell dalam proses menemukan jawaban penelitian, di antaranya : menentukan pertanyaan, melihat kompetensi dan relevansi narasumber, pada wawancara kali ini jenis wawancara yang dipilih adalah semi terstruktur, menentukan alat rekam dan menjalankan prosedur perekaman, merancang dan menggunakan panduan wawancara, menyempurnakan lebih lanjut pertanyaan wawancara melalui pengujian awal, meminta persetujuan narasumber dan membacakan kembali tujuan penelitian tersebut, waktu yang dibutuhkan untuk wawancara dan rencana penggunaan hasil wawancara (Cresswell, 2013: 227).

Pemilihan narasumber berdasarkan atas pertimbangan pengetahuan serta mengacu pada pertimbangan-pertimbangan tertentu yang dapat memberikan data terkait dengan permasalahan penelitian. Adapun narasumber (key person) yang dipilih sebagai informan, yaitu:

1. Putu Ardi (24 tahun), sebagai penggagas sekaligus ketua Sanggar Seni Anacaraka. Peneliti mendapatkan informasi program-program sanggar yang sudah dan belum terealisasi, dari tahun 2011, termasuk dalam strategi pengelolaannya.

2. I Wayan Suastawa, (42 tahun), sebagai pemilik sekaligus bertindak sebagai penasehat Sanggar Seni Anacaraka. Peneliti mendapatkan informasi terkait dengan keunggulan dan kelemahan dari Sanggar Seni Anacaraka.

Narasumber di atas menentukan strategi pengelolaan pada Sanggar Seni Anacaraka, karena mereka yang megetahui kekuatan, kelemahan, peluang dan ancaman yang dimiliki oleh Sanggar Seni Anacaraka. Informan lain digunakan untuk memperkuat data yang diperoleh dari informan kunci (key person), yaitu 1) Kepala Desa Selulung, Dinas Kebudayaan dan Pariwisata [untuk mengetahui peluang], 2) seniman, dan 3) masyarakat. 


\section{Kajian Sumber}

Penelitian ini mengumpulkan data-data sekunder yang berupa kajian teori dari beberapa buku-buku, jurnal ilmiah dan tesis yang dapat mendukung sumber data. Beberapa sumber data sekunder dikumpulkan dari beberapa buku, jurnal dan tesis dari perpustakaan Pascasarjana ISI Yogyakarta, koleksi pribadi dan beberapa referensi dari mahasiswa lain.

Pada penelitian ini data dianalisis menggunakan metode IFE (Internal Factor Analysis) dan EFE (Eksternal Faktor Analysis) yang bertujuan untuk mengetahui strategi yang tepat digunakan oleh Sanggar Seni Anacaraka berdasarkan hasil analisis SWOT. Dinyatakan oleh David bahwa matrik internal-eksternal memposisikan berbagai devisi suatu organisasi dalam tampilan sembilan sel sebagaimana diilustrasikan dalam tabel 1, 2 dan 3 (David, 2010: 344).

Tabel 1. The Internal Factor Evaluation (IFE) Matrik

\begin{tabular}{|l|l|l|l|l|}
\hline No & Strength (Keunggulan) & Bobot & ratting & Weighted score \\
\hline 1 & & & & \\
\hline 2 & & & & \\
\hline 3 & & & & \\
\hline Total & Weekness (Kelemahan) & & \\
\hline 1 & & & & \\
\hline 2 & & & & \\
\hline 3 & & & & \\
\hline
\end{tabular}

Tabel 2. The External Factor Evaluation (Efe) Matrik Key Person: I Putu Ardiyasa

\begin{tabular}{|c|c|c|c|c|}
\hline No & Opportunity (Peluang) & Bobot & ratting & Weighted score \\
\hline \multicolumn{5}{|c|}{ 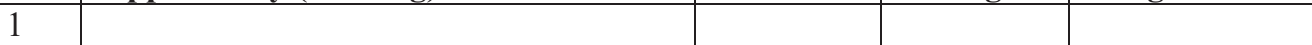 } \\
\hline \multicolumn{5}{|l|}{2} \\
\hline \multicolumn{5}{|l|}{3} \\
\hline \multicolumn{5}{|c|}{ Total } \\
\hline & Threats (Ancaman) & & & \\
\hline \multicolumn{5}{|c|}{1} \\
\hline \multicolumn{5}{|l|}{2} \\
\hline \multicolumn{5}{|l|}{3} \\
\hline - & Total & & & \\
\hline
\end{tabular}


TABEL 3. MATRIKS IFE dan EFE

\begin{tabular}{|c|c|c|c|c|}
\hline & & \multicolumn{3}{|c|}{ Skor Total IFE } \\
\hline & & Kuat & Rata-rata & Lemah \\
\hline & 4,0 & 3,0 & 2,0 & 1,0 \\
\hline Tinggi & 3,0 & I & II & III \\
\hline Menengah & 2,0 & IV & V & VI \\
\hline Rendah & 1,0 & VII & VIII & IX \\
\hline
\end{tabular}

\section{Temuan dan Pembahasan}

Dari kumpulan data yang diperoleh, selanjutnya dilakukan tahapan analisis, yaitu melalui analisis deskriptif (menjabarkan pokok-pokok hasil penelitian) dan analisis dua tahapan formulasi strategi yang terdiri dari tahapan masukan dengan menganalisis lingkungan eksternal dan internal (EFE dan IFE), tahapan pencocokkan, yaitu IE dan analisis SWOT.

Melalui beberapa hasil penelitian, maka ditemukan hal-hal penting yang terkait dengan pengelolaan Sanggar Seni Anacaraka di Kintamani, Bangli, dari faktor internal dan eksternal.

\section{Faktor Internal}

\begin{tabular}{|r|l|}
\hline \multicolumn{2}{|c|}{ Strength (Keunggulan) } \\
\hline 1 & Tenaga pengajar lulusan perguruan tinggi seni. \\
\hline 2 & $\begin{array}{l}\text { Pengemasan konsep latihan dengan permainan tradisional mampu } \\
\text { membuat anak tidak bosan. }\end{array}$ \\
\hline 3 & Sudah memiliki tempat yang luas untuk pengembangan usaha. \\
\hline 4 & Memiliki dukungan keluarga dan masyarakat. \\
\hline Weekness (Kelemahan) \\
\hline 1 & Kekurangan tenaga pengajar. \\
\hline 2 & Belum mendapatkan dukungan penuh dari pimpinan desa. \\
\hline 3 & Belum mampu melakukan pementasan kenaikan tingkat. \\
\hline 4 & Akses jaringan personal belum luas. \\
\hline 5 & Kurangnya promosi di media social. \\
\hline
\end{tabular}




\section{Faktor Eksternal}

\begin{tabular}{|l|l|}
\hline \multicolumn{2}{|l|}{ Opportunity (Peluang) } \\
\hline a. & $\begin{array}{l}\text { Antusiasme anak-anak dalam mengikuti kegiatan seni yang } \\
\text { sangat tinggi. }\end{array}$ \\
\hline b. & $\begin{array}{l}\text { Orang tua yang resah melihat anaknya melakukan kegiatan } \\
\text { yang kurang bermanfaat. }\end{array}$ \\
\hline & $\begin{array}{l}\text { Terdapat ruang seni yang fakum bisa diajak bekerja sama } \\
\text { untuk menghadirkan seni. }\end{array}$ \\
\hline d. & $\begin{array}{l}\text { Banyak bakat-bakat seni yang perlu mendapatkan ruang } \\
\text { pengembangan bakat. }\end{array}$ \\
\hline e. & Terdapat program desa yang menggalakkan kesenian. \\
\hline f. & Belum banyak ada organisasi sejenis. \\
\hline Threats (Ancaman) \\
\hline a. & Perubahan sosial, budaya, lingkungan demografi dan ekonomi. \\
\hline b. & Kemungkinan besar akan muncul pesaing-pesaing baru. \\
\hline c. & Ketakutan akan kehilangan masyarakat pendukung jika tidak \\
\hline d. & diantisipasi sejak dini. \\
\hline e. & Hiburan (bukan seni) di media televisi dan media yang lain \\
\hline f. & Kemakin marak. \\
\hline
\end{tabular}

\section{Analisis SWOT}

Dari analisis deskripstif di atas, maka selanjutnya dapat dilakukan analisis SWOT dengan memberikan bobot pada masing-masing faktor oleh narasumber kunci pada organisasi, yaitu I Putu Ardiyasa (owner) dan I Wayan Suastawa (penasehat).

\section{Tahap Masukan}

Melalui penyebaran kuesioner kepada beberapa responden, diperoleh data yang disajikan melalui beberapa tabel sebagai berikut:

\section{Pemberian Bobot Faktor}

Pada analisis internal dan eksternal, penentuan bobot dilakukan dengan mengajukan kuesioner kepada pihak pengelola Sanggar Seni Anacaraka, yaitu I Putu Ardiyasa (owner) dan I Wayan Suastawa sebagai orang tua yang mengetahui dengan jelas awal mula berdirinya sanggar ini. Bobot menunjukkan tingkat kepentingan suatu faktor terhadap keberhasilan organisasi dalam suatu kinerjanya.

Penentuan bobot pada setiap variabel digunakan skala 1,2,3.

Penilaian untuk setiap skala dapat dijelaskan sebagai berikut :

$1=$ jika indikator horisontal kurang penting daripada indikator vertikal

$2=$ jika indikator horisontal sama penting dengan indikator vertikal

$3=$ jika indikator horisontal lebih penting daripada indikator vertikal 
Tabel 1. Penilaian bobot faktor Internal (kekuatan \& kelemahan)

\begin{tabular}{|c|c|c|c|}
\hline $\begin{array}{c}\text { Faktor } \\
\text { Internal }\end{array}$ & I Putu Ardiyasa & I Wayan Suastawa & Rata-rata \\
\hline A & 0,091 & 0,091 & 0,091 \\
\hline B & 0,122 & 0,122 & 0,122 \\
\hline C & 0,167 & 0,167 & 0,167 \\
\hline D & 0,091 & 0,091 & 0,091 \\
\hline E & 0,106 & 0,106 & 0,106 \\
\hline F & 0,076 & 0,076 & 0,076 \\
\hline G & 0,083 & 0,083 & 0,083 \\
\hline H & 0,167 & 0,167 & 0,167 \\
\hline I & 0,167 & 0,167 & 0,167 \\
\hline \multicolumn{2}{|c|}{ Total Rata-rata } & 1,000 \\
\hline
\end{tabular}

\section{Keterangan:}

a. Tenaga pengajar lulusan perguruan tinggi seni.

b. Pengemasan konsep latihan dengan permainan tradisional mampu membuat anak tidak bosan.

c. Sudah memiliki tempat yang luas untuk pengembangan usaha.

d. Memiliki dukungan keluarga dan masyarakat.

e. Kekurangan tenaga pengajar.

f. Belum mendapatkan dukungan penuh dari pimpinan desa.

g. Belum mampu melakukan pementasan kenaikan tingkat.

h. Akses jaringan personal belum luas.

i. Kurangnya promosi di media sosial.

Tabel 1. Menunjukkan faktor internal pada pengelolaan Sanggar Seni Anacaraka Kintamani, Bangli yang memiliki bobot tertinggi adalah sudah memiliki tempat yang luas untuk pengembangan usaha.

Tabel 2. Penilaian bobot faktor Eksternal (peluang dan ancaman)

\begin{tabular}{|c|c|c|c|}
\hline $\begin{array}{c}\text { Faktor } \\
\text { Eksternal }\end{array}$ & $\begin{array}{c}\text { I Putu } \\
\text { Ardiyasa }\end{array}$ & $\begin{array}{c}\text { I Wayan } \\
\text { Suastawa }\end{array}$ & Rata-rata \\
\hline A & 0,083 & 0,117 & 0,141 \\
\hline B & 0,083 & 0,086 & 0,084 \\
\hline C & 0,116 & 0,090 & 0,161 \\
\hline D & 0,086 & 0,117 & 0,144 \\
\hline E & 0,086 & 0,049 & 0,110 \\
\hline F & 0,086 & 0,090 & 0,131 \\
\hline G & 0,116 & 0,117 & 0,174 \\
\hline H & 0,086 & 0,090 & 0,131 \\
\hline I & 0,060 & 0,068 & 0,094 \\
\hline
\end{tabular}




\begin{tabular}{|l|l|l|l|}
\hline $\mathrm{J}$ & 0,086 & 0,090 & 0,131 \\
\hline $\mathrm{K}$ & 0,052 & 0,049 & 0,076 \\
\hline $\mathrm{L}$ & 0,049 & 0,049 & 0,049 \\
\hline \multicolumn{2}{|l|}{ Total Rata-rata } \\
\multicolumn{2}{|l}{} \\
\hline
\end{tabular}

Keterangan :

A. Antusiasme anak-anak dalam mengikuti kegiatan seni yang sangat tinggi.

B. Orang tua yang resah melihat anaknya melakukan kegiatan yang kurang bermanfaat.

C. Terdapat ruang seni yang fakum bisa diajak bekerja sama untuk menghadirkan seni.

D. Banyak bakat-bakat seni yang perlu mendapatkan ruang pengembangan bakat.

E. Terdapat program desa yang menggalakkan kesenian.

F. Belum banyak ada organisasi sejenis.

G. Perubahan sosial, budaya, lingkungan demografi dan ekonomi.

H. Kemungkinan besar akan muncul pesaing-pesaing baru.

I. Ketakutan akan kehilangan masyarakat pendukung jika tidak diantisipasi sejak dini.

J. Hiburan (bukan seni) di media televisi dan media yang lain semakin marak.

K. Kemungkinan minimnya kolaborasi.

L. Anak-anak semakin besar malu untuk berkesenian.

Tabel 2. Menunjukkan bobot faktor eksternal pada pengelolaan Sanggar Seni Anacaraka di Kintamani Bangli yang memiliki bobot tertinggi adalah perubahan sosial, budaya, lingkungan demografi dan ekonomi.

Tabel 3. Pemberian Peringkat terhadap Keunggulan Perusahaan

\begin{tabular}{|r|l|c|c|c|}
\hline No & \multicolumn{1}{|c|}{ Strength (Keunggulan) } & $\begin{array}{c}\text { I Putu } \\
\text { Ardiyasa }\end{array}$ & $\begin{array}{c}\text { I Wayan } \\
\text { Suastawa }\end{array}$ & Rata-rata \\
\hline 1 & $\begin{array}{l}\text { Tenaga pengajar lulusan perguruan } \\
\text { tinggi seni. }\end{array}$ & 2 & 2 & 3 \\
\hline 2 & $\begin{array}{l}\text { Pengemasan konsep latihan dengan } \\
\text { permainan tradisional mampu membuat } \\
\text { anak tidak bosan. }\end{array}$ & 3 & 3 & 4 \\
\hline 3 & $\begin{array}{l}\text { Sudah memiliki tempat yang luas untuk } \\
\text { pengembangan usaha. }\end{array}$ & 4 & 3 & 3 \\
\hline 4 & $\begin{array}{l}\text { Memiliki dukungan keluarga dan } \\
\text { masyarakat }\end{array}$ & 3 & 4 & 2 \\
\hline
\end{tabular}

Tabel 3 Menunjukkan pemberian peringkat terhadap kunggulan Sanggar Seni Anacaraka yang memiliki nilai paling tinggi adalah indikator nomor 3, yaitu sudah memiliki tempat yang luas untuk pengembangan usaha. 
Tabel 4. Pemberian Peringkat terhadap Kelemahan Perusahaan

\begin{tabular}{|r|l|c|c|c|}
\hline No & \multicolumn{1}{|c|}{ Weekness (Kelemahan) } & $\begin{array}{c}\text { I Putu } \\
\text { Ardiyasa }\end{array}$ & $\begin{array}{c}\text { I Wayan } \\
\text { Suastawa }\end{array}$ & Rata-rata \\
\hline 1 & Kekurangan tenaga pengajar & 2 & 2 & 2 \\
\hline 2 & $\begin{array}{l}\text { Belum mendapatkan dukungan penuh dari } \\
\text { pimpinan desa }\end{array}$ & 3 & 3 & 3 \\
\hline 3 & $\begin{array}{l}\text { Belum mampu melakukan pementasan } \\
\text { kenaikan tingkat }\end{array}$ & 3 & 3 & 3 \\
\hline 4 & Akses jaringan personal belum luas & 1 & 1 & 1 \\
\hline 5 & Kurangnya promosi di media social & 1 & 1 & 1 \\
\hline
\end{tabular}

Tabel 4. Menunjukkan pemberian peringkat terhadap kelemahan pengelolaan Sanggar Seni Anacaraka yang memiliki nilai paling tinggi adalah indikator nomor 4 dan 5 yaitu akses jaringan personal belum luas dan kurangnya promosi di media sosial.

Tabel 5. Pemberian Peringkat terhadap Peluang Perusahaan

\begin{tabular}{|r|l|c|c|c|}
\hline No & \multicolumn{1}{|c|}{ Opportunity (Peluang) } & $\begin{array}{c}\text { I Putu } \\
\text { Ardiyasa }\end{array}$ & $\begin{array}{c}\text { I Wayan } \\
\text { Suastawa }\end{array}$ & Rata-rata \\
\hline 1 & $\begin{array}{l}\text { Antusiasme anak-anak dalam mengikuti } \\
\text { kegiatan seni yang sangat tinggi. }\end{array}$ & 2 & 4 & 3 \\
\hline 2 & $\begin{array}{l}\text { Orang tua yang resah melihat anaknya } \\
\text { melakukan kegiatan yang kurang bermanfaat }\end{array}$ & 3 & 2 & 2,5 \\
\hline 3 & $\begin{array}{l}\text { Terdapat ruang seni yang fakum bisa di ajak } \\
\text { bekerja sama untuk menghadirkan seni. }\end{array}$ & 4 & 3 & 3 \\
\hline 4 & $\begin{array}{l}\text { Banyak bakat-bakat seni yang perlu } \\
\text { mendapatkan ruang pengembangan bakat. }\end{array}$ & 4 & 4 & 2 \\
\hline 5 & $\begin{array}{l}\text { Terdapat program desa yang menggalakkan } \\
\text { kesenian. }\end{array}$ & 3 & 3 & 3 \\
\hline 6 & Belum banyak organisasi sejenis & 3 & 3 \\
\hline
\end{tabular}

Tabel 5. Menunjukkan pemberian peringkat pada peluang Sanggar Seni Anacaraka yang memiliki nilai tertinggi adalah indikator nomor 4, yaitu banyak bakat-bakat seni yang perlu mendapatkan ruang pengembangan bakat.

Tabel. 6 Pemberian Peringkat terhadap Ancaman Perusahaan

\begin{tabular}{|r|l|c|c|c|}
\hline No & \multicolumn{1}{|c|}{ Threats (Ancaman) } & $\begin{array}{l}\text { I Putu } \\
\text { Ardiyasa }\end{array}$ & $\begin{array}{l}\text { I Wayan } \\
\text { Suastawa }\end{array}$ & Rata-rata \\
\hline 1 & $\begin{array}{l}\text { Perubahan sosial, budaya, lingkungan } \\
\text { demografi dan ekonomi. }\end{array}$ & 1 & 1 & 2 \\
\hline 2 & $\begin{array}{l}\text { Kemungkinan besar akan muncul pesaing- } \\
\text { pesaing baru. }\end{array}$ & 3 & 3 & 3 \\
\hline 3 & $\begin{array}{l}\text { Ketakutan akan kehilangan masyarakat } \\
\text { pendukung jika tidak diantisipasi sejak dini. }\end{array}$ & 2 & 2 & 2 \\
\hline 4 & $\begin{array}{l}\text { Hiburan (bukan seni) di media televisi dan } \\
\text { media yang lain semakin marak. }\end{array}$ & 4 & 4 & 4 \\
\hline 5 & $\begin{array}{l}\text { Kemungkinan minimnya kolaborasi. } \\
\text { Anak-anak semakin besar malu untuk } \\
\text { berkesenian. }\end{array}$ & 4 & 4 & 4 \\
\hline
\end{tabular}


Tabel 6. Menunjukkan pemberian peringkat terhadap ancaman pengelolaan Sanggar Seni Anacaraka yang memiliki nilai paling tinggi adalah indikator nomor 1, yaitu perubahan sosial, budaya, lingkungan demografi dan ekonomi.

Tabel 7. The Internal Factor Evaluation (IFE) Matrik

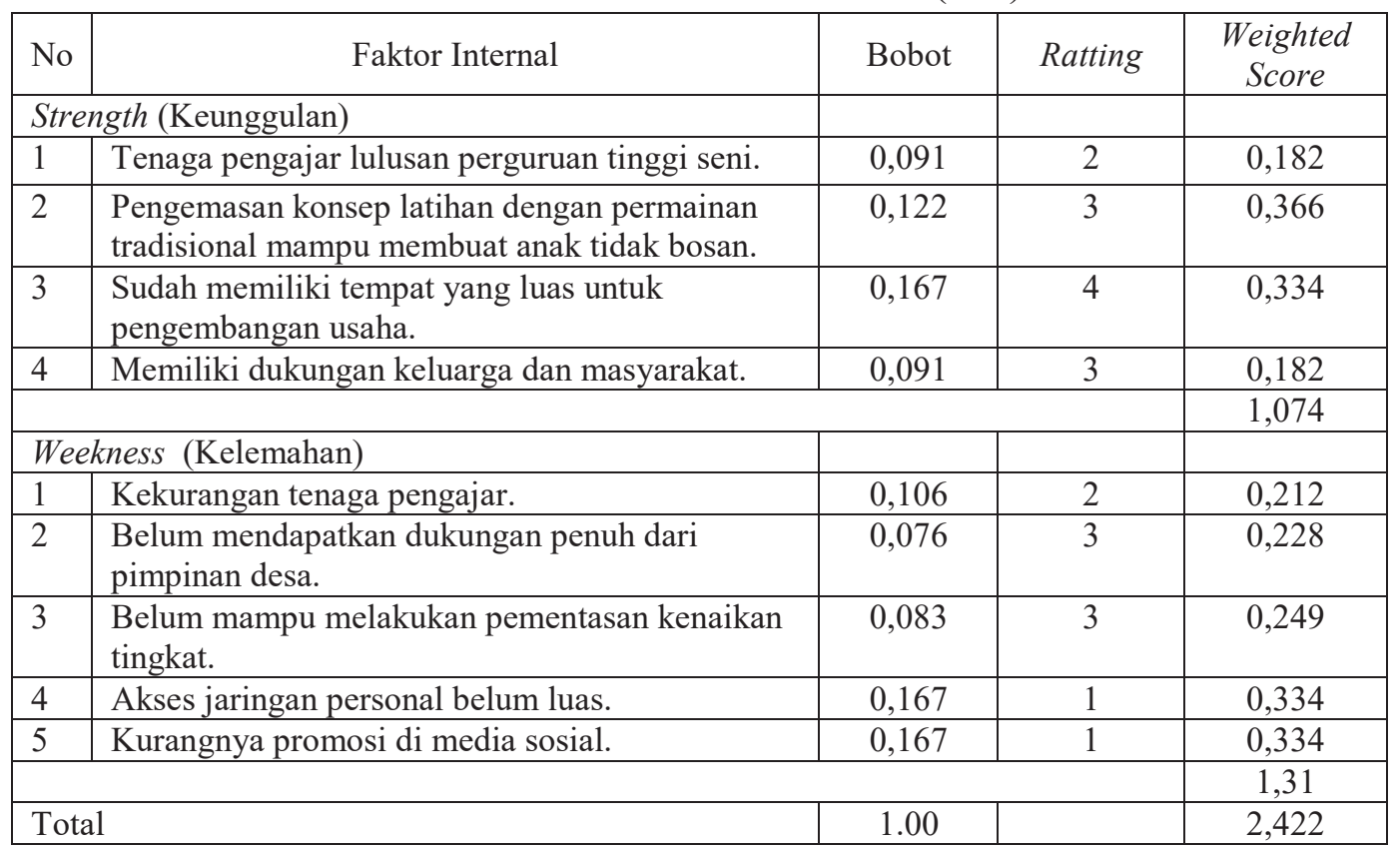

Tabel 7. Menunjukkan faktor internal pengelolaan Sanggar Seni Anacaraka yang memiliki bobot tertinggi adalah indikator "berkesenian secara konsisten tanpa menunggu tawaran" dengan jumlah 0,76 berbanding dengan jumlah 0,16 pada indikator kelemahan akses jaringan personal terbatas.

Tabel 8. The External Factor Evaluation (Efe) Matrik Key Person: I Putu Ardiyasa

\begin{tabular}{|r|l|c|c|c|}
\hline No & \multicolumn{1}{|c|}{ Opportunity (Peluang) } & Bobot & Ratting & $\begin{array}{c}\text { Weighted } \\
\text { score }\end{array}$ \\
\hline 1 & $\begin{array}{l}\text { Antusiasme anak-anak dalam } \\
\text { mengikuti kegiatan seni yang sangat } \\
\text { tinggi. }\end{array}$ & 0,141 & 3 & 0,423 \\
\hline 2 & $\begin{array}{l}\text { Orang tua yang resah melihat } \\
\text { anaknya melakukan kegiatan yang } \\
\text { kurang bermanfaat. }\end{array}$ & 0,084 & 2,5 & 0,210 \\
\hline 3 & $\begin{array}{l}\text { Terdapat ruang seni yang fakum } \\
\text { bisa diajak bekerja sama untuk } \\
\text { menghadirkan seni. }\end{array}$ & 0,161 & 3,5 & 0,563 \\
\hline 4 & $\begin{array}{l}\text { Banyak bakat-bakat seni yang perlu } \\
\text { mendapatkan ruang pengembangan } \\
\text { bakat. }\end{array}$ & 0,144 & 4 & 0,576 \\
\hline 5 & $\begin{array}{l}\text { Terdapat program desa yang } \\
\text { menggalakkan kesenian. }\end{array}$ & 0,110 & 2 & 0,220 \\
\hline 6 & Belum banyak organisasi sejenis. & 0,131 & 3 & 0,393 \\
\hline \multicolumn{3}{|l|}{} \\
\hline
\end{tabular}




\begin{tabular}{|c|c|c|c|c|}
\hline \multicolumn{2}{|r|}{ Threats (Ancaman) } & \multirow[b]{2}{*}{0,174} & \multirow[b]{2}{*}{1} & \multirow[b]{2}{*}{0,174} \\
\hline 1 & $\begin{array}{l}\text { Perubahan sosial, budaya, } \\
\text { lingkungan demografi dan ekonomi. }\end{array}$ & & & \\
\hline 2 & $\begin{array}{l}\text { Kemungkinan besar akan muncul } \\
\text { pesaing-pesaing baru. }\end{array}$ & 0,131 & 2 & 0,262 \\
\hline 3 & $\begin{array}{l}\text { Ketakutan akan kehilangan } \\
\text { masyarakat pendukung jika tidak } \\
\text { diantisipasi sejak dini. }\end{array}$ & 0,094 & 3 & 0,282 \\
\hline 4 & $\begin{array}{l}\text { Hiburan (bukan seni) di media } \\
\text { televisi dan media yang lain } \\
\text { semakin marak. }\end{array}$ & 0,131 & 2 & 0,262 \\
\hline 5 & Kemungkinan minimnya kolaborasi. & 0,076 & 4 & 0,304 \\
\hline 6 & $\begin{array}{l}\text { Anak-anak semakin besar malu } \\
\text { untuk berkesenian. }\end{array}$ & 0,049 & 4 & 0,196 \\
\hline & Total & & & 1,480 \\
\hline \multicolumn{2}{|c|}{ TOTAL } & 1.000 & & 3,865 \\
\hline
\end{tabular}

Tabel 8. Menunjukkan faktor eksternal pada pengelolaan Sanggar Seni Anacaraka yang memiliki bobot tertinggi pada peluang adalah indikator "banyak bakat-bakat seni yang perlu mendapatkan ruang pengembangan bakat sebesar 0,48 " dan pada ancaman adalah indikator perubahan sosial, budaya, lingkungan demografi dan ekonomi.

Keterangan:

\begin{tabular}{|c|c|}
\hline \multicolumn{2}{|c|}{ Lingkungan Eksternal } \\
\hline $\begin{aligned} & \text { Aspek Peluang : } \\
& \text { rating } 4= \text { respon sangat } \\
& \text { superior, } \\
& \text { rating } 3= \text { respon di atas } \\
& \text { rata-rata, } \\
& \text { rating } 2= \text { respon rata-rata } \\
& \text { rating } 1= \text { respon di bawah } \\
& \text { rata-rata }\end{aligned}$ & $\begin{array}{l}\text { Aspek Ancaman : } \\
\text { rating } 4=\text { respon di bawah } \\
\\
\text { rata-rata, } \\
\text { rating } 3=\text { respon rata-rata, } \\
\text { rating } 2=\text { respon di atas rata-rata, } \\
\text { rating } 1=\text { respon sangat superior }\end{array}$ \\
\hline \multicolumn{2}{|c|}{ Lingkungan Internal } \\
\hline $\begin{array}{l}\text { Aspek Kekuatan : } \\
\text { rating } 4=\text { sangat kuat, } \\
\text { rating } 3=\text { kuat, } \\
\text { rating } 2=\text { lemah dan } \\
\text { rating } 1=\text { sangat lemah }\end{array}$ & $\begin{array}{l}\text { Aspek Kelemahan: } \\
\text { rating } 4=\text { sangat lemah, } \\
\text { rating } 3=\text { lemah, } \\
\text { rating } 2=\text { kuat, dan } \\
\text { rating } 1=\text { sangat kuat }\end{array}$ \\
\hline
\end{tabular}

\section{Tahap Pencocokkan}

Hasil perhitungan di atas, diperoleh hasil IFE sebesar 2,422 dan EFE sebesar 3,865. Angka tersebut diperoleh dari penjumlahan antara hasil dua key person di bagi 2. Angka tersebut selanjutnya dapat menggambarkan posisi Pengelolaan Sanggar Seni Anacaraka pada matrik. 
TABEL 9. Matriks Ife dan EFE Sanggar Seni Ancaraka

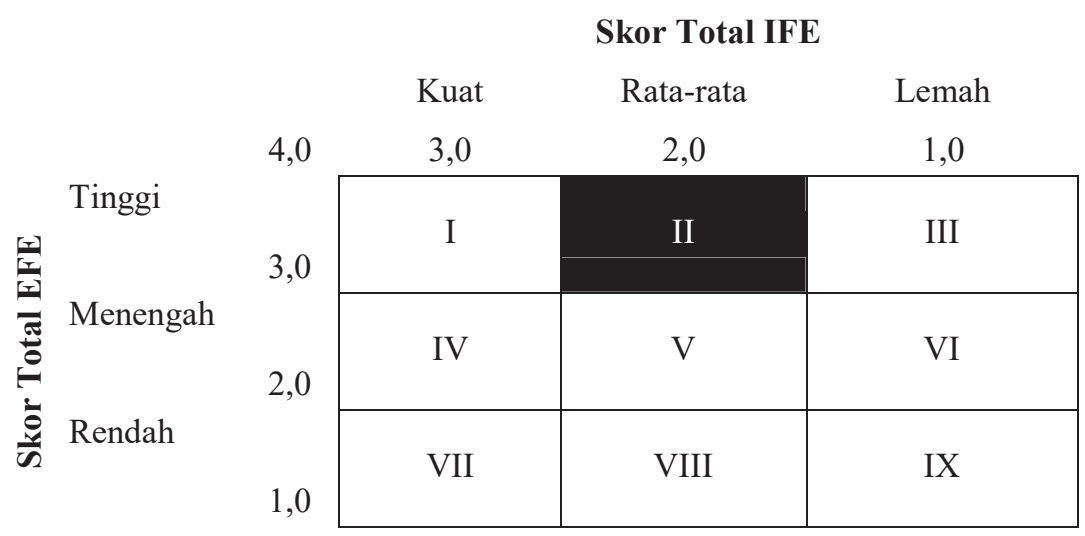

Berdasarkan matrik di atas, menunjukkan bahwa pengelolaan Sanggar Seni Anacaraka harus tumbuh dan membangun karena berada pada posisi II. Ada beberapa strategi yang dipakai dalam mempertahankan usaha ini, yaitu penetrasi pasar dan pengembangan produk. Sanggar Seni Anacaraka mulai melakukan strategi integrasi ke depan dan ke belakang dengan di dukung pendekatan-pendekatan penawaran dengan berbagai pihak yang ingin dilibatkan, serta melakukan pengembangan produk baik jasa (pertunjukkan) dan barang (bangunan, kostum).

Tahap selanjutnya juga dilakukan pencocokkan melalui kuadran analisis SWOT, untuk itu diperlukan bobot skor Faktor Internal dan bobot skor Faktor Eksternal. Bobot skor Faktor Internal diperoleh dari bobot skor Kekuatan dikurangi Kelemahan, sedangkan bobot skor Faktor Eksternal diperoleh dari Peluang dikurangi Ancaman.

$\begin{array}{lcc}\text { - Bobot Skor Internal } & \text { : Keunggulan - Kelemahan } & \\ & \mathbf{1 , 0 7 4}-\mathbf{1 , 3 1 0} & =\mathbf{- 0 , 2 3 6} \\ \text { - Bobot Skor Eksternal } & : \quad \text { Peluang }- \text { Ancaman } & \\ & \mathbf{3 , 8 6 5}-\mathbf{2 , 3 8 5} & =\mathbf{1 , 4 8 0}\end{array}$

Hasil diperoleh dari pengurangan indikator pada faktor eksternal dan faktor internal jadi dapat diperoleh kuadran 0,555; 1.000 .

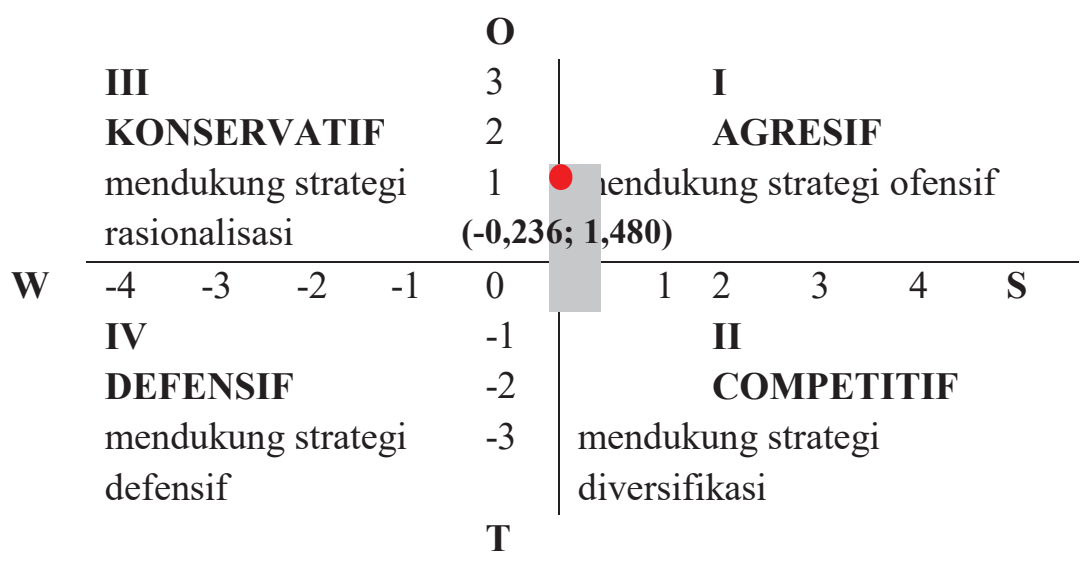


Kuadran Analisis SWOT pengelolaan Sanggar Seni Anacaraka di Kintamani Bali, Menunjukkan posisi pada kuadran III, sehingga diperlukan pemilihan strategi berupa penggunaan setiap kekuatan (strenght) untuk mengadapi segala ancaman (treath) dengan melakukan penetrasi pasar pengembangan pasar, pengembangan produk dan diversifikasi terkait.

Tabel 10. Matriks SWOT Pengelolaan Sanggar Seni Anacaraka di Kintamani

\begin{tabular}{|c|c|c|}
\hline $\begin{array}{l}\text { FAKTOR } \\
\text { EKSTERNAL }\end{array}$ & \begin{tabular}{|l} 
Strength (S) Kekuatan \\
1. \\
Tenaga pengajar \\
lulusan perguruan \\
tinggi seni. \\
2. \\
Pengemasan konsep \\
latihan dengan \\
permainan \\
tradisional mampu \\
membuat anak tidak \\
bosan. \\
3. \\
Sudah memiliki \\
tempat yang luas \\
untuk \\
pengembangan \\
usaha. \\
4. \\
Memiliki dukungan \\
keluarga dan \\
masyarakat.
\end{tabular} & \begin{tabular}{|l} 
Weakness (W) Kelemahan \\
1. Kekurangan tenaga \\
pengajar. \\
2. Belum mendapatkan \\
dukungan penuh dari \\
pimpinan desa. \\
3. Belum mampu \\
melakukan pementasan \\
kenaikan tingkat. \\
4. Akses jaringan \\
personal belum luas. \\
5. Kurangnya promosi di \\
media sosial.
\end{tabular} \\
\hline $\begin{array}{l}\text { Opportunity (Peluang) } \\
\text { 1. Antusiasme anak-anak } \\
\text { dalam mengikuti } \\
\text { kegiatan seni yang } \\
\text { sangat tinggi. } \\
\text { 2. Orang tua yang resah } \\
\text { melihat anaknya } \\
\text { melakukan kegiatan } \\
\text { yang kurang } \\
\text { bermanfaat. } \\
\text { 3. Terdapat ruang } \\
\text { seni yang fakum } \\
\text { bisa diajak bekerja } \\
\text { sama untuk } \\
\text { menghadirkan seni. } \\
\text { 4. Terdapat program } \\
\text { desa yang } \\
\text { menggalakkan } \\
\text { kesenian. } \\
\text { 5. Belum banyak } \\
\text { organisasi sejenis. }\end{array}$ & $\begin{array}{l}\text { SO } \\
\text { 1.Bekerja sama dengan } \\
\text { masyarakat dan } \\
\text { pemerintah desa dan } \\
\text { pemerintah daerah, } \\
\text { seniman dan para } \\
\text { pendidik seni untuk } \\
\text { terlibat dalam } \\
\text { pengembangan dan } \\
\text { menjaga } \\
\text { keberlangsungan } \\
\text { sanggar serta bekerja } \\
\text { (S1, S2, S3, S4, S5, } \\
\text { O1, O3, O4). } \\
\text { 2.Membangun gedung } \\
\text { dan menambah } \\
\text { fasilitas pendukung } \\
\text { pelatihan (O2, O4, } \\
\text { S3). }\end{array}$ & $\begin{array}{l}\text { WO } \\
\text { Merekrut tenaga pengajar } \\
\text { lulusan SMK seni atau } \\
\text { ISI dengan memperluas } \\
\text { jaringan personal melalui } \\
\text { jaringan sosial (O5, W1, } \\
\text { W2,W4,W5). }\end{array}$ \\
\hline
\end{tabular}




\begin{tabular}{|c|c|c|}
\hline Treath (Ancaman) & ST & WT \\
\hline $\begin{array}{l}\text { 1.Perubahan sosial, } \\
\text { budaya, lingkungan } \\
\text { demografi dan } \\
\text { ekonomi. } \\
\text { 2. Kemungkinan besar } \\
\text { akan muncul pesaing- } \\
\text { pesaing baru. } \\
\text { 3. Ketakutan akan } \\
\text { kehilangan } \\
\text { masyarakat } \\
\text { pendukung jika tidak } \\
\text { diantisipasi sejak dini. } \\
\text { 4. Hiburan (bukan seni) } \\
\text { di media televisi dan } \\
\text { media yang lain } \\
\text { semakin marak. } \\
\text { 5.Kemungkinan } \\
\text { minimnya kolaborasi. } \\
\text { 6.Anak-anak semakin } \\
\text { besar malu untuk } \\
\text { berkesenian. }\end{array}$ & $\begin{array}{l}\text { 1. Untuk meyakinkan } \\
\text { publik,Sanggar Seni } \\
\text { Anacaraka harus } \\
\text { konsisten dan } \\
\text { mengembangkan } \\
\text { strategi yang agresif } \\
\text { membangun kerja } \\
\text { sama agar tetap bisa } \\
\text { menjalankan kegiatan } \\
\text { yang tidak } \\
\text { membosankan dengan } \\
\text { kemasan menarik dan } \\
\text { mementaskan hasil } \\
\text { pelatihan pada saat- } \\
\text { saat tertentu (T1, T2, } \\
\text { T3). } \\
\text { 2. Mendatangkan } \\
\text { seniman, sastrawan } \\
\text { dan motivator lain } \\
\text { untuk memberikan } \\
\text { orasi dalam rangka } \\
\text { memotivasi para anak- } \\
\text { anak serta membuat } \\
\text { karya seni bersama } \\
\text { anak-anak (T2, T5). }\end{array}$ & $\begin{array}{l}\text { 1.Mengadakan kenaikan } \\
\text { tingkat dan mencoba } \\
\text { untuk masuk ke ranah } \\
\text { festival untuk menguji } \\
\text { mental tampil anak-anak } \\
\text { (T2, T3, T4,T6, W3, W4, } \\
\text { W5) } \\
\text { 2.Mencari donatur yang } \\
\text { mau membantu untuk } \\
\text { mengembangkan } \\
\text { pembangunan fasilitas } \\
((\mathrm{T} 2, \mathrm{~T} 3, \mathrm{~T} 4, \mathrm{~T} 5) .\end{array}$ \\
\hline
\end{tabular}

\section{Kesimpulan}

Sanggar Seni Anacaraka berusaha untuk menerapkan strategi pelatihan yang menarik dan unik agar peserta didik tertarik untuk terus mengikuti proses pelatihan serta banyak calon peserta lain yang ingin bergabung. Konsep pelatihan dengan kombinasi permainan dan dongeng membuat para murid lebih aktif, kreatif dan cinta pada proses yang diikuti.

Terbukti sampai saat ini anak-anak sanggar antusias mengikuti proses pelatihan. Segmentasi pasar Sanggar Seni Anacaraka masih menawarkan produk dan jasa kepada kelompok Banjar atau kampung di sekitar lokasi berdirinya sanggar, yaitu banjar Sabang Selatan dan Utara, Banjar Nyawah, Banjar Luahan, dan sekitarnya. Untuk sementara ini pihak pengelola belum menerima peserta didik dari luar daerah, karena jangkauan pasar masih sempit dan fasilitas pendukung belum lengkap. Tersedia dua jenis produk, jasa pelatihan tari dan drama tari, dan produk pertunjukan berupa tari dan drama tari.

Berdasarkan hasil analisis di atas, langkah-langkah yang diterapkan oleh Sanggar Seni Ancaraka berkaitan dengan variasi strategi yaitu, strategi penetrasi pasar, harus tumbuh dan membangun, Integrasi ke belakang (backward integration), Integrasi Harisontal (horisontal integration). 


\section{Kepustakaan}

Harwanto, Setyo. 2015. Peningkatan Potensi dan Pegembangan Atraksi Wisata Budaya Batik, di Desa Jarum. Jurnal Tata Kelola Seni vol. 1 No. 1 hlm 1.

Juwita, Ida Ayu Eva Ratna. 2015. Strategi Pemasaran Museum Wayang Kekayon Yogyakarta dalam Meningkatkan Jumlah Pengunjung. Jurnal Tata Kelola Seni vol. 1 No. 1 hlm 49.

Seramasara, I Gusti Ngurah. 2005. Keberadaan Wayang Kulit Bali sebagai Dinamika Budaya di Era Modernisasi. Jurnal Wayang Vol. 1 Hal 3.

Cresswel, Jhon W. 2015. Penelitian Kualitatif dan Desain Riset (edisi bahasa Indonesia). Yogyakarta: Pustaka Pelajar.

Kotler, Philip dan Keller, Kevin Lane. 2009. Manajemen Pemasaran (edisi 3). Jakarta: Erlangga.

David, Fred R. 2010. Srategic Management: concept. Pearson Prentice Hall: Pearson Education.

Kaiser, Michael M. dan Egan, Brett 2011. The Cycle. Kennedy Center: The DeVos Institute of Arts Management. 